\title{
Purification of Chloride Salts for Concentrated Solar Power Applications
}

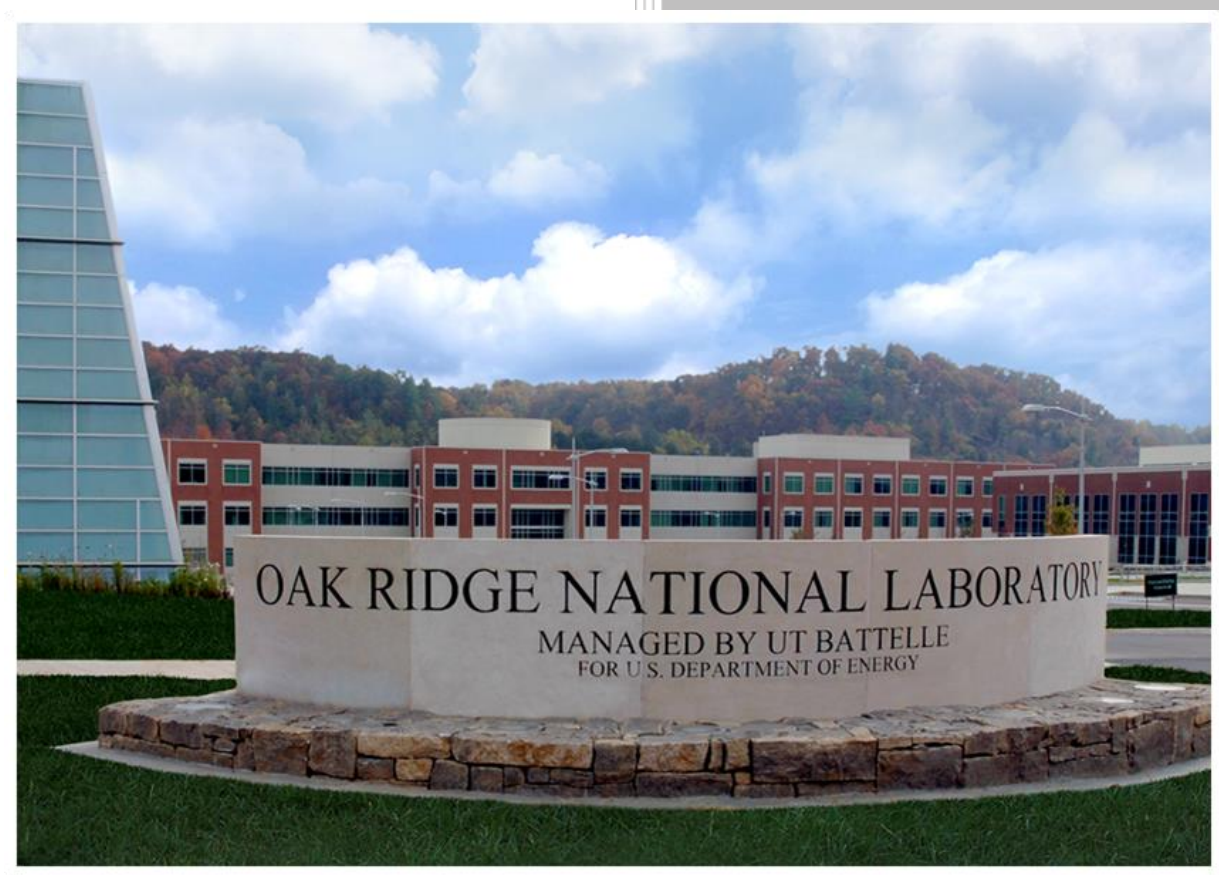

Approved for public release.

Distribution is unlimited.

Richard T. Mayes

J. Matthew Kurley

Phillip W. Halstenberg

Abbey McAlister

Dino Sulejmanovic

Stephen Raiman

Sheng Dai

Bruce Pint

December 13, 2018 


\title{
DOCUMENT AVAILABILITY
}

Reports produced after January 1, 1996, are generally available free via US Department of Energy (DOE) SciTech Connect.

Website www.osti.gov

Reports produced before January 1, 1996, may be purchased by members of the public from the following source:

\author{
National Technical Information Service \\ 5285 Port Royal Road \\ Springfield, VA 22161 \\ Telephone 703-605-6000 (1-800-553-6847) \\ TDD 703-487-4639 \\ Fax 703-605-6900 \\ E-mail info@ntis.gov \\ Website http://classic.ntis.gov/
}

Reports are available to DOE employees, DOE contractors, Energy Technology Data Exchange representatives, and International Nuclear Information System representatives from the following source:

Office of Scientific and Technical Information

PO Box 62

Oak Ridge, TN 37831

Telephone 865-576-8401

Fax 865-576-5728

E-mail reports@osti.gov

Website http://www.osti.gov/contact.html

This report was prepared as an account of work sponsored by an agency of the United States Government. Neither the United States Government nor any agency thereof, nor any of their employees, makes any warranty, express or implied, or assumes any legal liability or responsibility for the accuracy, completeness, or usefulness of any information, apparatus, product, or process disclosed, or represents that its use would not infringe privately owned rights. Reference herein to any specific commercial product, process, or service by trade name, trademark, manufacturer, or otherwise, does not necessarily constitute or imply its endorsement, recommendation, or favoring by the United States Government or any agency thereof. The views and opinions of authors expressed herein do not necessarily state or reflect those of the United States Government or any agency thereof. 
Chemical Sciences Division

\title{
Purification of Chloride Salts for Concentrated Solar Power Applications
}

\author{
Author(s) \\ Richard T. Mayes \\ J. Matthew Kurley \\ Phillip W. Halstenberg \\ Abbey McAlister \\ Dino Sulejmanovic \\ Stephen Raiman \\ Sheng Dai \\ Bruce Pint
}

Date Published:

December 13, 2018

\author{
Prepared by \\ OAK RIDGE NATIONAL LABORATORY \\ Oak Ridge, TN 37831-6283 \\ managed by \\ UT-BATTELLE, LLC \\ for the \\ US DEPARTMENT OF ENERGY \\ under contract DE-AC05-00OR22725
}





\section{CONTENTS}

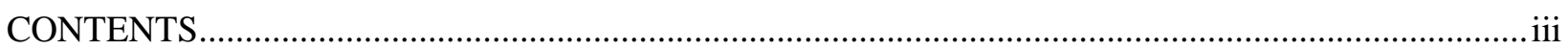

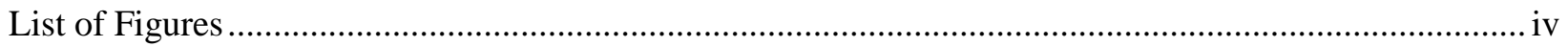

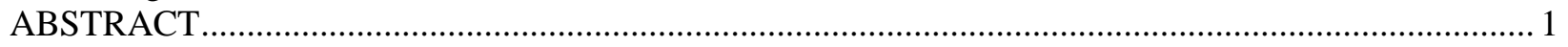

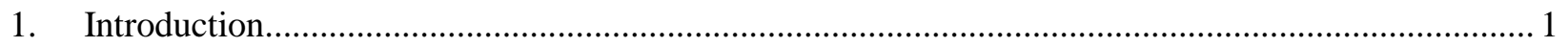

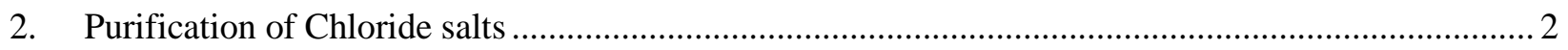

2.1 Dehydration of Magnesium Chloride-Containing Salts............................................... 2

2.2 Carbochlorination of Magnesium Chloride-contianing Salts............................................... 3

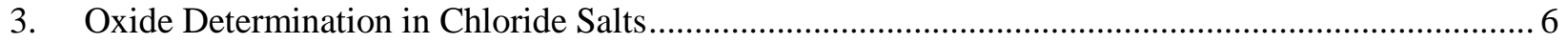

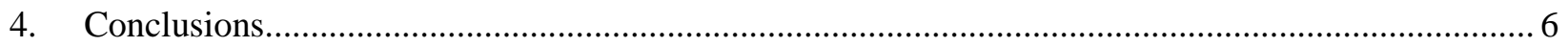

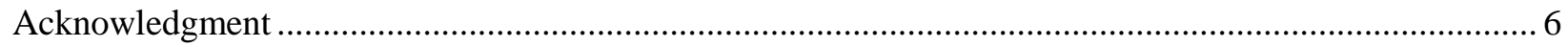

Appendices................................................................................................................. 1

Appendix A. Ellingham Diagrams for Dehydration and Deoxygenation of Magnesium Chloride ............. 2

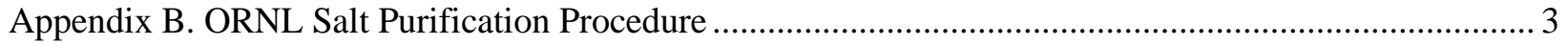

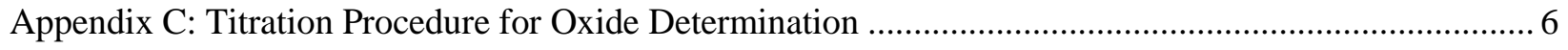

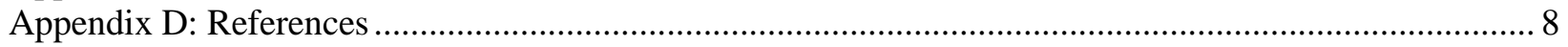




\section{LIST OF FIGURES}

Figure 1: Oxide content of the ICL "solar salt" dried via carnallite method............................................ 3

Figure 2: Ellingham diagram for the removal of oxide (as $\mathrm{MgO}$ ) using $\mathrm{HCl}$, phosgene, and $\mathrm{CCl}_{4}$.

Lines in plot are color coded to the corresponding reactions listed on the left. The

Equation 1,2, \& 3 in green within the plot correspond to the dominant reaction for temperatures within that zone defined by the dotted lines.......................................................

Figure 3: Schematic of chloride salt purification reactor............................................................... 5

Figure 4: Ellingham diagrams for the dehydration of magnesium chloride with $\mathrm{HCl}, \mathrm{CO} / \mathrm{Cl}_{2}$, $\mathrm{COCl}_{2}$, and $\mathrm{CCl}_{4}$

Figure 5: Ellingham diagrams for the deoxygenation of magnesium chloride with $\mathrm{HCl}, \mathrm{CO} / \mathrm{Cl}_{2}$,

$\mathrm{COCl}_{2}$, and $\mathrm{CCl}_{4}$. 


\begin{abstract}
The increased interest in high temperature molten salt technology, including concentrated solar power (CSP), has resulted in an increased need for high purity alkali and alkaline earth chloride salts. One lingering question remains in the technoeconomic analysis: 'How clean is clean enough?' High-quality corrosion experiments are necessary to design alloys with enhanced corrosion resistance, and ultimately to realize a cost-effective CSP facility. To conduct high-quality, reproducible corrosion experiments, high purity salt with known impurity compositions must be achievable. Commercial high purity salts are qualified on the basis of metal impurity content, with cost increasing significantly as purity increases. However, non-metallic impurities such as oxygen and moisture content are extremely relevant to concentrated solar or nuclear applications are. For this reason, efforts to clean salts at Oak Ridge National Laboratory (ORNL) have centered upon a modified carbochlorination process which addresses oxygen and moisture-based impurities. This report will focus on the modified carbochlorination procedure utilized to purify magnesium chloride-containing salts for concentrated solar power applications.
\end{abstract}

\title{
1. INTRODUCTION
}

The increased interest in a broad suite of renewable energy technologies has resulted in a resurgence of high temperature molten salt research through a focus on energy derived from solar and nuclear sources. ${ }^{1-}$

12 The concentrated solar power application is driven by the storage of solar-derived thermal energy. The use of chloride salts over the current state-of-the-art, i.e. nitrate salts, arises from the desire for greater efficiency arising from higher temperatures and larger temperature differentials $(\Delta \mathrm{T})$, defined as the difference between the maximum operational temperature and the melt temperature $\left(\mathrm{T}_{\mathrm{m}}\right) .{ }^{1}$ Chloride salts present higher stability at the desired temperatures relative to the current nitrate salt state-of-the-art. Fluoride salts are an alternative to chloride salts and were used in previous nuclear applications. Although widely studied, fluoride salts are not favored due to the apparent cost. ${ }^{1}$ These two parameters when coupled with the economics of salt production, have focused the high temperature thermal fluid development on chloride salts. However, high purity commercial salts from venders are expensive. The commercial high purity salts also provide purities based upon metal content, which is not necessarily the critical purity factor when considering corrosivity. Most of the high purity salts have varying levels of oxide content, which is not reported within the product certificate of analysis. This realization provides economic relief, as cheaper salts could be used since oxide removal is also required of the high purity salts, as well as increased the need for an understanding of how to clean chloride salts.

Lower purity salts, such as anhydrous magnesium chloride $\left(\mathrm{MgCl}_{2}\right.$, Millipore-Sigma product M8266), have $\leq 3 \%$ water with $\leq 0.5 \%$ "Water Insolubles." Large scale salt suppliers, such as the ICL Group (Haifa, Israel) supply a chloride-based "solar salt" that is purified from salt obtained near the Dead Sea region containing predominately sodium chloride, magnesium chloride, and potassium chloride (Na-K$\mathrm{Mg}-\mathrm{Cl})$. This salt was provided to ORNL through the DOE-EERE Solar Energy Technology Office (SETO) program arriving with reportedly $0.4 \%$ water as a component of the supplied salt. However, not unlike fine chemical suppliers Millipore-Sigma and Alfa Aesar, the salt arrived in a plastic container with no other desiccant. Magnesium chloride is a well-known desiccant therefore the actual water content is based upon how long the container is opened to ambient atmosphere and the age of the salt.

These factors are important due to the structural transformation of magnesium chloride in the presence of water or oxygen upon melting. Upon melting, water will form magnesium oxide $(\mathrm{MgO})$ arising from the dehydrochlorination of magnesium chloride (1). ${ }^{4,13}$ This occurs through a magnesium hydroxide intermediate evolving an equivalent of hydrogen chloride per hydroxide added to the magnesium. The hydrogen chloride generated is highly corrosive and can mask the effects of the salt on the containment materials. Therefore, to understand the fundamental mechanisms of corrosion, a need exists for a 
comprehensive cleaning procedure that sets a framework for future, more economical purification processes through an understanding of the fundamental corrosion mechanisms.

$$
\mathrm{MgCl}_{2}+2 \mathrm{H}_{2} \mathrm{O} \stackrel{\Delta}{\rightarrow} \mathrm{Mg}(\mathrm{OH})_{2}+2 \mathrm{HCl}(\mathrm{g}) \stackrel{\Delta}{\rightarrow} \mathrm{MgO}+\mathrm{H}_{2} \mathrm{O}
$$

While some have proposed a cation effect for corrosion, ${ }^{14}$ the presence of oxide must be negated prior to any study correlating corrosion to salt type. ${ }^{15}$ Several methods have been proposed to purify magnesium chloride-based salts. ${ }^{16-21}$ Given the methods and the need for clean salt, ORNL has chosen the carbochlorination method to enable a unique, reproducible baseline for the salt. This also provides a salt that can be fully characterized with a pedigree that is associated with the salt cleaning process more than the individual salt. Herein we report the purification process utilized to generate ultra-dry, low oxide content chloride salts for concentrated solar applications.

\section{PURIFICATION OF CHLORIDE SALTS}

\subsection{DEHYDRATION OF MAGNESIUM CHLORIDE-CONTAINING SALTS}

Magnesium chloride-containing salts will be discussed as analogous to magnesium chloride. This is due to the thermodynamics of oxygen content within alkali chloride-magnesium chloride salts. The magnesium chloride waters of hydration are involved in the hydroxide formation. In fact, only the monohydrate reportedly leads to the hydroxide formation. This means a significant amount of water can be removed via thermal or chemical dehydration. However, only chemical dehydration can remove the last hydration water without forming as much hydroxide as simply heating the salt. ${ }^{22}$ Hydrogen chloride has been used to dehydrate magnesium chloride. ${ }^{16,19}$ Previously, ORNL reported the dehydration using hydrogen chloride and the carnallite method comparing and contrasting the two methods. ${ }^{19}$ Based on this, the carnallite method using ammonium chloride was chosen as the dehydration method. Here, magnesium chloride is mixed with ammonium chloride $\left(\mathrm{NH}_{4} \mathrm{Cl}\right)$ prior to thermally decomposing the ammonium chloride to remove the water (Eqn. 3). The ammonia $\left(\mathrm{NH}_{3}\right)$ and hydrogen chloride $(\mathrm{HCl})$ atmosphere arising from the thermal decomposition of $\mathrm{NH}_{4} \mathrm{Cl}$ facilitated the removal of the water.

$$
\mathrm{MgCl}_{2} \cdot \mathrm{nH}_{2} \mathrm{O}+\mathrm{NH}_{4} \mathrm{Cl} \stackrel{\Delta}{\rightarrow} \mathrm{MgCl}_{2}+\mathrm{NH}_{3}(g)+\mathrm{HCl}(\mathrm{g})+\mathrm{H}_{2} \mathrm{O}
$$


Air sensitive techniques should be utilized during this process to ensure the dried salt does not contact water post-drying. Challenges are also introduced within this process that require periodic attention. The primary hazard is pressurizing the reactor due to the reformation of $\mathrm{NH}_{4} \mathrm{Cl}$ in the cold zones. This recombination has the potential to clog the reactor exhaust resulting in either a stopped flow or, at worst, a catastrophic failure of the dehydration reactor. The formation of $\mathrm{NH}_{4} \mathrm{Cl}$ facilitates recycling the precursor salt with moderate yields $(\sim 50$ $60 \%)$, although we currently do not recycle the salt.

This process also does not remove all oxide from the salt. Significant oxide exists postdrying. Figure 1 illustrates the oxide content of the ICL solar salt after drying using the carnallite method described above. Due to the other components of the salt, e.g. sulfate, boron, zinc, etc., the oxide content is reported in molal $(m)$ since molal does not require us to know the exact composition of the salt. As seen in Figure 1, with the exception of sample L2-013e, the oxide content is consistently above $5,000 \mu \mathrm{m}$. This indicates further purification is required prior to use for corrosion studies.

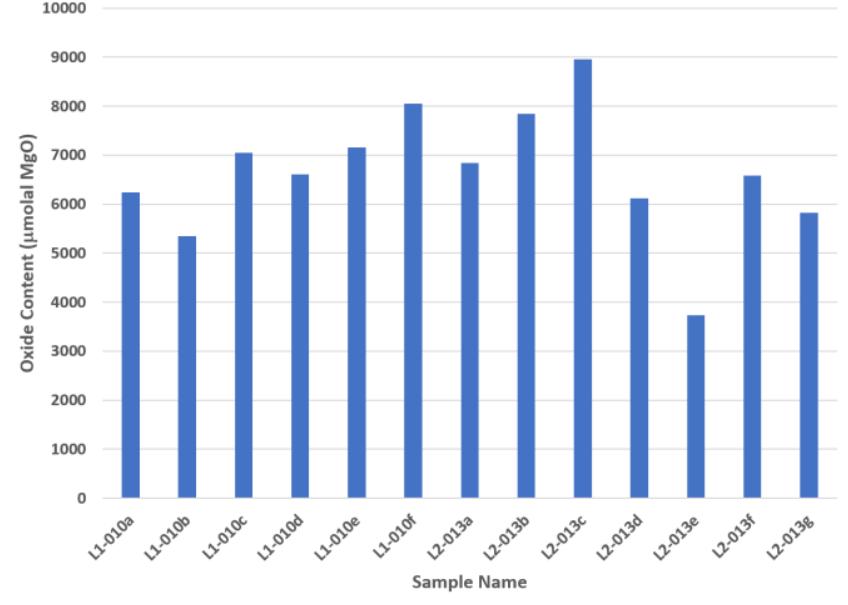

Figure 1: Oxide content of the ICL "solar salt" dried via carnallite method.

\subsection{CARBOCHLORINATION OF MAGNESIUM CHLORIDE-CONTIANING SALTS}

Carbochlorination was chosen as the purification method due to past experience at ORNL. There are three methods reported to perform carbochlorinations: (1) carbon monoxide(CO)/chlorine $\left(\mathrm{Cl}_{2}\right){ }^{16}{ }^{16}$ (2) phosgene $\left(\mathrm{COCl}_{2}\right),{ }^{18}$ and (3) carbon tetrachloride $\left(\mathrm{CCl}_{4}\right) \cdot{ }^{17}$ Each method has advantages and disadvantages, such as cost and scale when using carbon tetrachloride vs. ease of handling. The $\mathrm{CO} / \mathrm{Cl}_{2}$ method is reported to be scalable ${ }^{16}$ yet handles toxic gases. Each method also has different thermodynamic considerations for the removal of oxide $($ as $\mathrm{MgO})$, oxygen $\left(\mathrm{O}_{2}\right)$, and water $\left(\mathrm{H}_{2} \mathrm{O}\right)$. The Ellingham diagram and associated equations are presented in Figure 2 using data from the JANAF tables. 


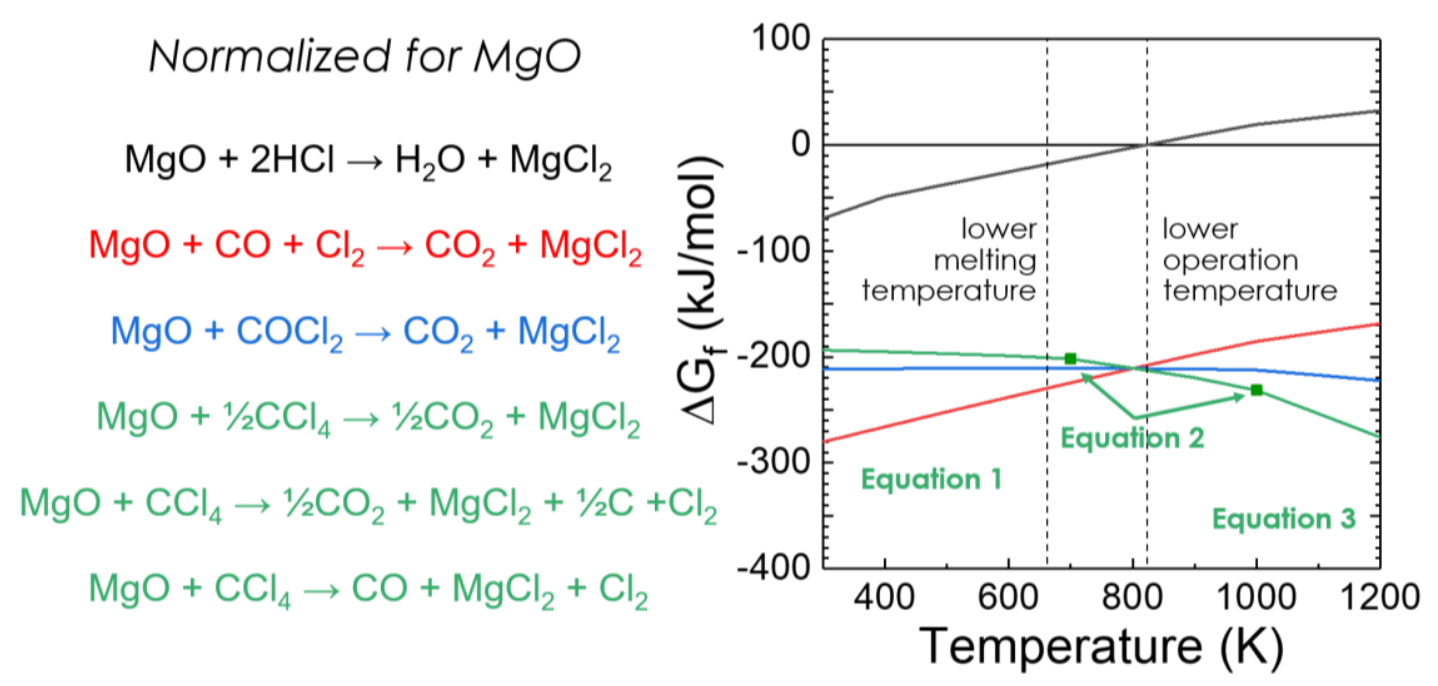

Figure 2: Ellingham diagram for the removal of oxide (as $\mathrm{MgO}$ ) using $\mathrm{HCl}$, phosgene, and $\mathrm{CCl}_{4}$. Lines in plot are color coded to the corresponding reactions listed on the left. The Equation $1,2, \& 3$ in green within the plot correspond to the dominant reaction for temperatures within that zone defined by the dotted lines.

In Figure 2, we can see that the purification by $\mathrm{HCl}(\mathrm{g})$ is not as effective as carbochlorination for the conversion of $\mathrm{MgO}$ to $\mathrm{MgCl}_{2}$ (black line). Carbochlorination by $\mathrm{CO} / \mathrm{Cl}_{2}$ suffers from decreasing efficiency as the temperature increases (red line). Phosgene $\left(\mathrm{COCl}_{2}\right)$ has stable carbochlorination efficiency as a function of temperature (blue line) while carbon tetrachloride becomes better as the temperature increases (green line). The increase in effectiveness is related to the thermal decomposition of $\mathrm{CCl}_{4}$ into reactive species that promote the chlorination of magnesium oxide as illustrated by the more favorable thermodynamic properties of the reactions. Note, as the temperature increases, the favorable reaction changes as well, signified by the three reactions listed for the carbochlorination with $\mathrm{CCl}_{4}$. Similar behavior is observed for water removal and deoxygenation (Appendix A).

Carbochlorination requires melting the salt. This improves contact between the chlorinating agent (as a gas) and the salt (as a liquid) and reduces limitations associated with gas diffusion through solids. Carbochlorination, as previously stated is not without hazards. The use of carbon tetrachloride requires appropriate controls as the products of the chlorination are potentially chlorine and phosgene. This is due to several factors, including residence time of the gas in the liquid, gas bubble size, and temperature. A schematic of the reactor utilized for the purification of chloride salts at ORNL is presented in Figure 3. The enclosed system was easily achieved using standard air-sensitive techniques to ensure all joints are leak-tight thus minimizing the possibility of exposure to phosgene or chlorine. Pressure relief valves are included to minimize over-pressurization while also minimizing the possibility for backpressure on the salt sparge tube. The system has three traps to minimize toxic or acidic gas exposure prior to exhaust in the fume hood: (1) an empty trap to prevent backflow from the aqueous traps into the molten salt and catch liquid byproducts, (2) a metal containing water trap with mossy zinc or magnesium turnings, and (3) a $5 \mathrm{M}$ base trap (i.e. $5 \mathrm{M} \mathrm{KOH}$ ). The metal will react with the gases to form zinc hydroxide or magnesium hydroxide, thus presenting an effective indicator when the trap should be recycled. The second significant feature is the need to purify the ultra-high purity (UHP)-grade argon (Airgas, 99.999\% purity)

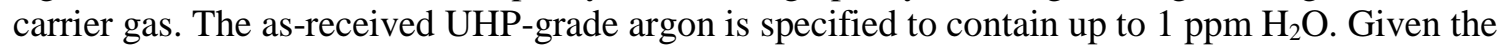
deliquescence of magnesium chloride and the thermodynamically favorable oxide formation, this water must be removed prior to contacting the melted salt. This is done by layering phosphorus pentoxide $\left(\mathrm{P}_{2} \mathrm{O}_{5}\right)$ with Drierite ${ }^{\mathrm{TM}}$ in an inline gas trap. The Drierite ${ }^{\mathrm{TM}}$ is to prevent particulate $\mathrm{P}_{2} \mathrm{O}_{5}$ from entering the gas stream and contacting the salt. Using Drierite ${ }^{\mathrm{TM}}$ instead of sand or glass wool provides a second drying agent while still preventing particulate ingress. 


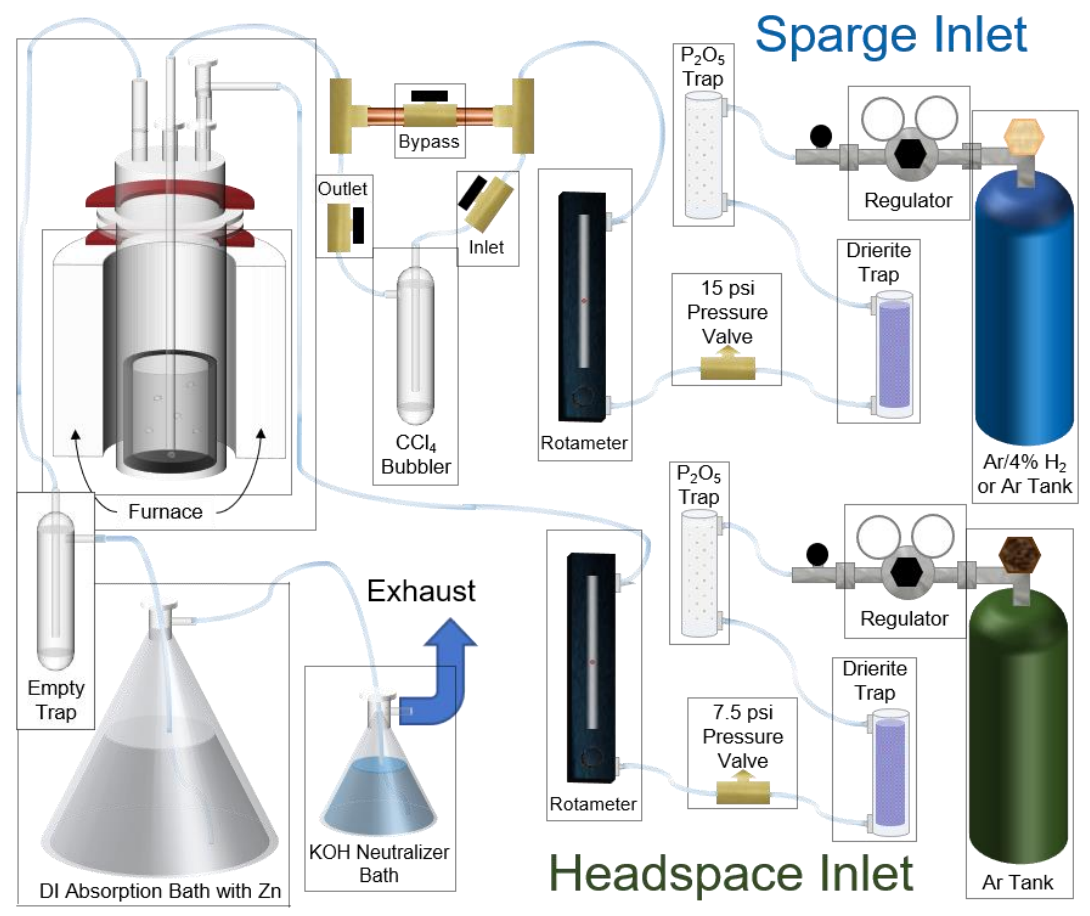

Figure 3: Schematic of chloride salt purification reactor.

Purification of ICL's solar salt proceeded similarly to high quality, lab-grade salts. The interesting caveat to the purification was the removal of some contaminants during the carbochlorination process. As seen in Table 1, bromide, iron, manganese, \& zinc concentrations decreased during the carbochlorination. The chloride salt is thermodynamically favored over the bromide salt. This allows the bromide to be removed as a volatile $\mathrm{Br}_{2}$ which is decomposed in the traps. The metals are removed as volatile chlorides and collected in the aqueous traps.

Table 1: Nominal solar salt specifications provided by ICL with post-purification analysis. *Not detectable **Analysis is on-going to determine sulfate and boron concentrations as well as verify bromide concentrations.

\begin{tabular}{|c|c|c|c|c|c|c|c|c|c|c|c|}
\hline Element & $\mathbf{K}$ & $\mathbf{M g}$ & $\mathbf{N a}$ & $\mathbf{B}$ & $\mathbf{F e}$ & $\mathbf{M n}$ & $\mathbf{S O 4}$ & $\mathbf{Z n}$ & $\mathbf{B r}$ & $\mathbf{C l}$ & $\mathbf{H}_{2} \mathbf{O}$ \\
& $(\boldsymbol{\%})$ & $(\boldsymbol{\%})$ & $(\boldsymbol{\%})$ & $(\mathbf{p p m})$ & $(\mathbf{p p m})$ & $(\mathbf{p p m})$ & $(\mathbf{p p m})$ & $(\mathbf{p p m})$ & $(\boldsymbol{\%})$ & $(\boldsymbol{\%})$ & $(\boldsymbol{\%})$ \\
\hline Nominal $^{\mathbf{1}}$ & 21.2 & 12.8 & 1.33 & 2.5 & 4 & 2.8 & 186 & 1 & 0.58 & 58.2 & 5 \\
\hline As Received $^{19.7}$ & 12.8 & 1.55 & $* *$ & 4.67 & 3.36 & $* *$ & 0.3 & 0.61 & 61 & 5 \\
\hline Carbochlorination & 20.1 & 12.9 & 1.62 & $* *$ & 1.65 & 1.20 & $* *$ & 0.04 & $* *$ & 65 & $*$ \\
\hline $\begin{array}{c}\text { Carnallite } \\
\text { Dehydration }\end{array}$ & 18.4 & 11.9 & 1.76 & $* *$ & 5.63 & 2.46 & $* *$ & 0.31 & 0.39 & $\mathrm{n} / \mathrm{a}$ & $*$ \\
\hline Lab-Grade Salt & 29.3 & 9.1 & $\mathrm{n} / \mathrm{a}$ & $*$ & $*$ & $*$ & $*$ & $*$ & $\mathrm{n} / \mathrm{a}$ & $\mathrm{n} / \mathrm{a}$ & $*$ \\
\hline
\end{tabular}

Oxide concentration measurements for the purified solar salts was performed via an acid titration as described in Section 3.0. The oxide content for Loop 1 was $173 \mu \mathrm{m}$. This represents $\sim 30$-fold reduction in oxide content from the dehydration step. 


\section{OXIDE DETERMINATION IN CHLORIDE SALTS}

Oxide is given significant attention due to the influence on corrosion that oxygen exerts on a system. ${ }^{2-4,9}$ Measurement of the oxide content in magnesium chloride melts via acid consumption is a well-known technique, usually utilizing a back titration method. ${ }^{2,13}$ The method utilized at ORNL includes back titration; however, due to the low oxide content present in the salts after carbochlorination, an acid neutralization titration is utilized. Since all titrations are performed after melting the solid at $750{ }^{\circ} \mathrm{C}$, it can be assumed that the predominant base concentration arises from the presence of $\mathrm{MgO}$. This is based on the thermal decomposition of $\mathrm{Mg}(\mathrm{OH})_{2}$ and $\mathrm{Mg}(\mathrm{OH}) \mathrm{Cl}$ to form $\mathrm{MgO} .{ }^{22}$ This assumption based on literature data enables the use of equation 2.

$$
\mathrm{MgO}+2 \mathrm{HCl} \rightarrow \mathrm{MgCl}_{2}+\mathrm{H}_{2} \mathrm{O}
$$

In the base neutralization method, $1-2 \mathrm{~g}$ of salt is added to $250 \mathrm{~mL}$ of deionized water $(18.2 \mathrm{M} \Omega)$ and allowed to equilibrate. Residual solid indicates a magnesium oxide concentration higher than the solubility limit in water. The salt produced from the carnallite method and carbochlorination are both below the solubility limit. Dilute hydrochloric acid $(0.01 \mathrm{M} \mathrm{HCl})$ is added via micropipette in defined intervals allowing sufficient equilibration time. The $\mathrm{pH}$ and potential, measured by an ORION $\mathrm{pH}$ meter with a silver/silver chloride junction $\mathrm{pH}$ electrode, is recorded and monitored during each addition. In high levels of $\mathrm{MgO}$, drift of the $\mathrm{pH}$ due to the slow dissolution of $\mathrm{MgO}$ is observed. If the $\mathrm{MgO}$ content is too far above the solubility limit, the acid consumption method, i.e. back titration, is utilized.

\section{CONCLUSIONS}

The purification of magnesium chloride-containing salts requires two steps: dehydration and oxide removal. This process provides a baseline to correlate the corrosion to various impurities, such as oxide content and other ions, whether cationic or anionic. This will be necessary as lower purity salts are utilized due to economic considerations. The carbochlorination process utilized by ORNL provides a baseline with an oxide content well below 500 micromolal, with the oxide content measured by a simple acid consumption titration. This reproducible method can be used to produce salts with consistent and quantifiable chemistries for corrosion experiments, while facilitating the search for an economic purity through the provision of a baseline salt purity to benchmark any companion salt for concentrated solar applications.

\section{ACKNOWLEDGMENT}

This work was funded by the U. S. Department of Energy, Office of Energy Efficiency \& Renewable Energy, Solar Technologies Office. 
APPENDICES 


\section{APPENDIX A. ELLINGHAM DIAGRAMS FOR DEHYDRATION AND DEOXYGENATION OF MAGNESIUM CHLORIDE}

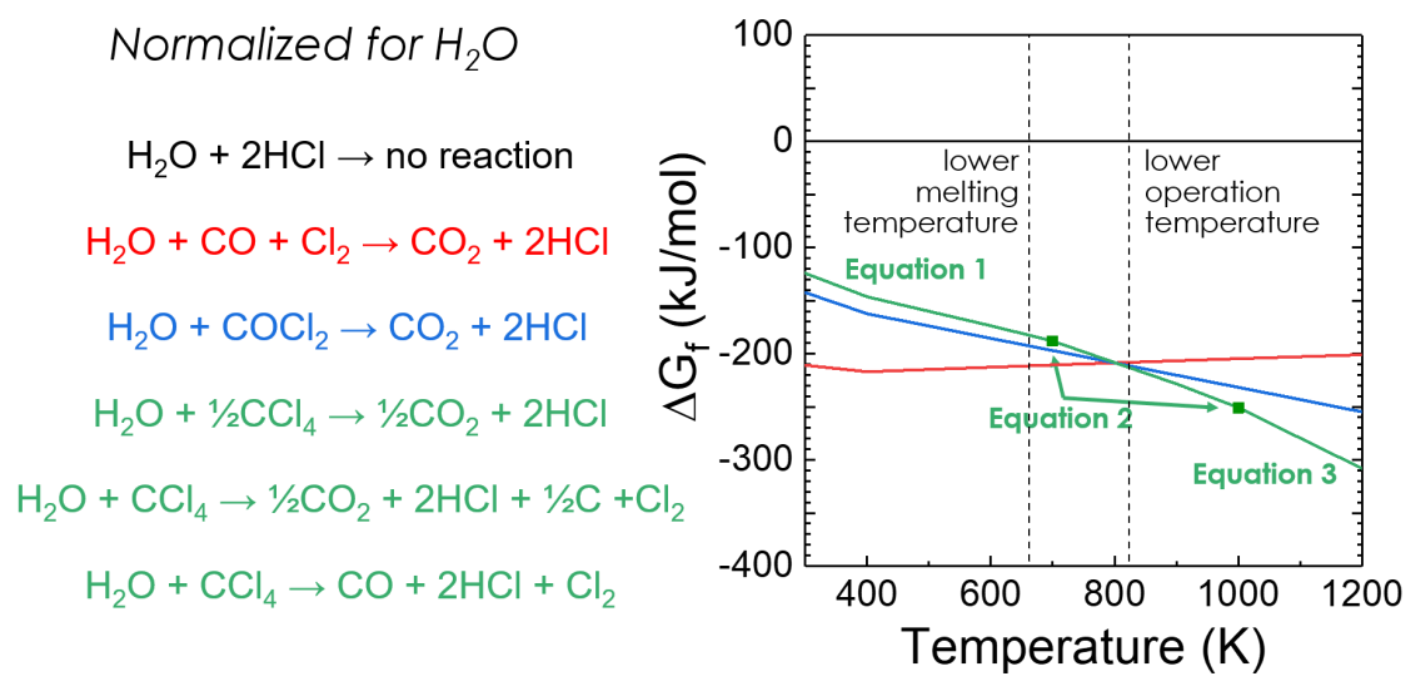

Figure 4: Ellingham diagrams for the dehydration of magnesium chloride with $\mathrm{HCl}, \mathrm{CO} / \mathrm{Cl}_{2}, \mathrm{COCl}_{2}$, and $\mathrm{CCl}_{4}$.

$$
\begin{gathered}
\text { Normalized for } \mathrm{O}_{2} \\
\mathrm{O}_{2}+4 \mathrm{HCl} \rightarrow 2 \mathrm{H}_{2} \mathrm{O}+2 \mathrm{Cl}_{2} \\
\mathrm{O}_{2}+2 \mathrm{CO} \rightarrow 2 \mathrm{CO}_{2} \\
\mathrm{O}_{2}+2 \mathrm{COCl}_{2} \rightarrow 2 \mathrm{CO}_{2}+2 \mathrm{Cl}_{2} \\
\mathrm{O}_{2}+\mathrm{CCl}_{4} \rightarrow \mathrm{CO}_{2}+2 \mathrm{Cl}_{2} \\
\mathrm{O}_{2}+2 \mathrm{CCl}_{4} \rightarrow \mathrm{CO}_{2}+\mathrm{C}+4 \mathrm{Cl}_{2} \\
\mathrm{O}_{2}+2 \mathrm{CCl}_{4} \rightarrow 2 \mathrm{CO}+4 \mathrm{Cl}_{2}
\end{gathered}
$$

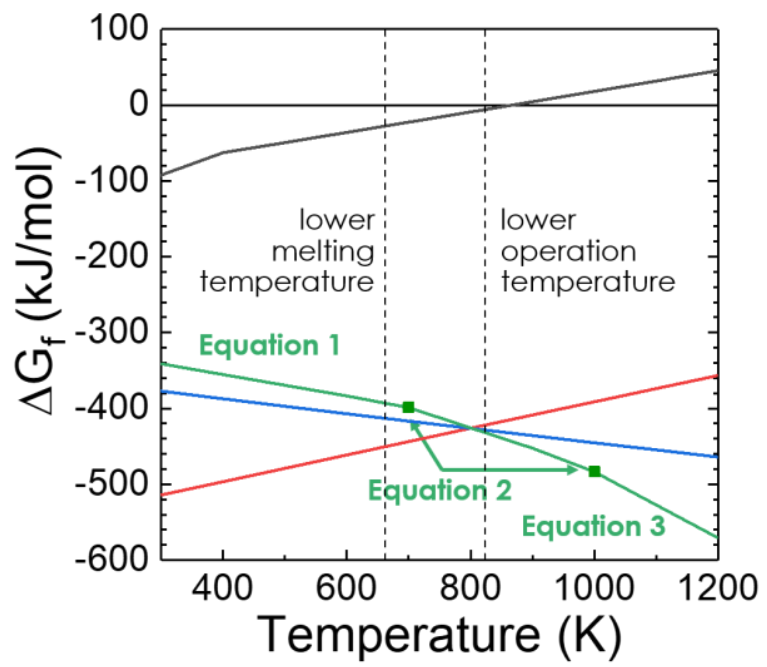

Figure 5: Ellingham diagrams for the deoxygenation of magnesium chloride with $\mathrm{HCl}, \mathrm{CO} / \mathrm{Cl}_{2}, \mathrm{COCl}_{2}$, and $\mathrm{CCl}_{4}$. 


\section{APPENDIX B. ORNL SALT PURIFICATION PROCEDURE}

Cleaning and drying. All glassware, including the reactor body and crucibles, were thoroughly cleaned in a $\mathrm{KOH} /$ isopropanol base bath and rinsed with deionized water several times. The glassware was dried and stored in a drying oven at $105{ }^{\circ} \mathrm{C}$ for more than $2 \mathrm{~h}$ prior to each use.

Glovebox. The glovebox atmosphere was maintained by UHP argon with oxygen and water impurities being less than $1 \mathrm{ppm}$. Transferring items, including the loaded reactor, into the glovebox was done by pumping down the antechamber for 30 minutes followed by flushing the antechamber with UHP Ar. This was repeated five times before the items were introduced into the glovebox.

Reactor and crucibles. Crucibles were made from fused quartz by the ORNL glass shop with dimensions of $300 \mathrm{~mm}$ (1) x $90 \mathrm{~mm}$ ID x $95 \mathrm{~mm}$ OD with a flat bottom and were annealed at $1250{ }^{\circ} \mathrm{C}$ for 30 minutes prior to first use. The Reactor body (Technical Glass Products, Inc., special order) with an O-ring flange was made from fused quartz with dimensions of $450 \mathrm{~mm}$ (1) x $101 \mathrm{~mm}$ ID x $106 \mathrm{~mm}$ OD with a flat bottom.

After loading the crucible with salt into the reactor body, the reactor was fitted with a 3-port glass reactor head and was sealed by a Viton ${ }^{\circledR}$ O-ring using a 3-point screw clamp. The three ports on the reactor head were used for headspace purging with UHP Ar, chemical sparging with connected UHP Ar purge option (middle port) and an outlet port. The port connections were standard 24/40 tapered joints fitted and sealed with Teflon liners to ensure proper seal during the purification process without seizing.

Furnace. The reactor furnace used for purification steps was a Thermo Scientific Lindberg Blue M splittube furnace oriented vertically and equipped with a Lindberg Blue M temperature controller. A K-type thermocouple was inserted in the middle of the heat zone and used to control temperature.

Chemicals. All gases were of ultra-high purity grade and further dried using phosphorus pentoxide $\left(\mathrm{P}_{2} \mathrm{O}_{5}\right) /$ Drierite ${ }^{\mathrm{TM}}$ moisture traps in the inlet lines. Carbon tetrachloride $\left(\mathrm{CCl}_{4}\right.$, Acros Organics) was $99 \%$ pure with water being less than $0.01 \%$. Ammonium chloride $\left(\mathrm{NH}_{4} \mathrm{Cl}\right.$, Fisher Scientific) was ACS grade $(99.5 \%)$ pure. "Solar Salt" was obtained from ICL (Haifa, Israel) and provided through the U. S. Department of Energy, Solar Technologies Office (SETO).

Inlet/Outlet gas lines. The inlet gas lines were made from 304 stainless steel, Tygon ${ }^{\circledR}$ tubing and quartz (sparge tube). Gas lines were equipped with needle valves and 7.5 psi \& 15 psi pressure relief valves. The outlet assembly was made from a glass bump trap (connected to the outlet port) with Teflon tubing prior to an empty primary glass vacuum trap. Downstream from the vacuum trap, the secondary trap contained $5 \mathrm{~L}$ DI water and $\sim 100 \mathrm{~g}$ of $\mathrm{M}^{0}(\mathrm{M}=\mathrm{Mg}$ or $\mathrm{Zn})$ followed by $1.5 \mathrm{~L}$ of $5 \mathrm{M} \mathrm{KOH}$. The gas outlet from the $\mathrm{KOH}$ trap was exhausted via the chemical fume hood.

System Flush. Prior to heating and purification steps, the salt-loaded and assembled reactor was flushed with UHP Ar, flow rate $>1 \mathrm{~L} / \mathrm{min}$, for 15 minutes prior to steps 2, 3 and 4.

$\mathrm{NH}_{4} \mathrm{Cl}$ Carnallite Dehydration Method. $500 \mathrm{~g}$ of ICL salt was weighed in air and mixed with $250 \mathrm{~g}$ of $\mathrm{NH}_{4} \mathrm{Cl}$ in a plastic jar for 5 minutes to ensure homogeneity and to break up any large chunks. The mixed salt was placed in a dry quartz crucible and the reactor was assembled as described above. For this step in the purification process, the sparge tube was not necessary and the middle port was closed by a rubber septum. After purging with UHP Ar for 15 minutes, the reactor body was placed in the furnace ensuring that the salt was in the middle of the heat zone and the reactor head was $~ 10$ inches above the furnace. 
The reactor body was secured by a chain clamp. The heating profile for the Carnallite purification step is shown in Table 1 below.

Table 1. Heating/Cooling profile for the $\mathrm{NH}_{4} \mathrm{Cl}$ Carnallite Dehydration

\begin{tabular}{|c|c|c|c|}
\hline $\begin{array}{c}\text { Temperature } \\
\left({ }^{\circ} \mathbf{C}\right)\end{array}$ & $\begin{array}{c}\text { Ramp rate } \\
\left({ }^{\circ} \mathbf{C} / \mathbf{m i n}\right)\end{array}$ & Dwell time (hr) & $\begin{array}{c}\text { Gas Flow Rate } \\
(\mathbf{L} / \mathbf{m i n})\end{array}$ \\
\hline $25-450$ & 10 & 2 & $>1$ \\
\hline $450-750$ & 10 & 1 & $>1$ \\
\hline $750-25$ & Natural cooling & & $>1$ \\
\hline
\end{tabular}

After heating, the reactor head gas outlet assembly was quickly removed and replaced with a rubber septum with a needle pushed through for gas outlet. A second needle was pushed through the septum with UHP Ar flow (>0.5 L/min). Next, the gas inlet headspace assembly was taken out and replaced with a rubber septum. Finally, the UHP Ar inlet and outlet needles were removed simultaneously to ensure Ar atmosphere inside the reactor. The reactor was immediately transferred into the glovebox. The single solid chunk of the salt that was at the bottom of the crucible was removed, broken in pieces and stored in clean and dry Mason jars. $\sim 2 \mathrm{~g}$ of the salt was weighed and separated for oxide analysis by titrations as described below.

Carbochlorination with $\mathrm{CCl}_{4}$ sparging. The $\mathrm{NH}_{4} \mathrm{Cl}$ treated salt was loaded into a dry crucible inside the glovebox. The crucible was carefully placed into the reactor body and the reactor was assembled inside the glovebox. The reactor head ports were closed by rubber septa before bringing the reactor body outside. This ensured that the salt does not get exposed to air during transferring. Once the reactor was brought outside of the glovebox, a needle with UHP Ar flow (> $1 \mathrm{~L} / \mathrm{min}$ ) was inserted into one of the rubber septa. A second outlet needle was inserted shortly after. With UHP Ar flow going inside the reactor body, the headspace assembly (with flowing UHP Ar) was quickly fitted into one of the ports by removing one of the rubber septa. The UHP Ar needle was removed at this point. Next, a 30-inch sparge quartz tube (O.D. $12 \mathrm{~mm}$, I.D. $8 \mathrm{~mm}$ ) was fitted into the middle port of the reactor head. The fitting was made from tapered glass, Teflon ${ }^{\circledR}$ screw fitting with a nitrile $10 \mathrm{~mm}$ O-ring and Teflon ${ }^{\circledR}$ liner for the tapered glass. The screw assembly allows for sliding of the sparge tube in and out of the salt melt during various stages of the purification process. After the sparge tube was inserted, the reactor was placed into the furnace and the final rubber septum was quickly replaced by the outlet glass assembly. The bubbling in the $\mathrm{DI} / \mathrm{M}^{0}$ and $5 \mathrm{M} \mathrm{KOH}$ baths ensured that no leaks in the system were detected. Once the reactor body and thermocouple were in place, the heating was initiated. Table 2 provides the heating and cooling profile for the $\mathrm{CCl}_{4}$ Sparge purification step.

Table 2. Heating/Cooling profile for the $\mathrm{CCl}_{4}$ Sparge Purification

\begin{tabular}{|c|c|c|c|c|}
\hline $\begin{array}{c}\text { Temperature } \\
\left({ }^{\circ} \mathbf{C}\right)\end{array}$ & $\begin{array}{c}\text { Ramp rate } \\
\left({ }^{\circ} \mathbf{C} / \text { min) }\right.\end{array}$ & Dwell time (hr) & $\begin{array}{c}\text { Gas Flow Rate } \\
(\mathbf{L} / \mathbf{m i n})\end{array}$ & Comments \\
\hline $25-750$ & 10 & & $>0.5$ & $\begin{array}{c}\text { Dip the sparge tube } \\
\text { in the melt }\end{array}$ \\
\hline 750 & N/A & $65 \mathrm{~h}$ & $>0.5$ & ${\text { Start bubbling } \mathrm{CCl}_{4}}^{\text {N/A }}$ \\
\hline 750 & & $>0.5$ & $\begin{array}{c}\text { Stop bubbling } \\
\text { CCl }_{4}, \text { remove the } \\
\text { sparge tube from } \\
\text { the melt }\end{array}$ \\
\hline $750-25$ & Natural cooling & & $>0.5$ & \\
\hline
\end{tabular}

After heating, the reactor was handled in the same manner as for the $\mathrm{NH}_{4} \mathrm{Cl}$ purification step. The salt was stored in Mason jars inside the glovebox before the next purification step. 
UHP Ar/ $\mathrm{H}_{2}$ sparge. The $\mathrm{CCl}_{4}$ treated salt was placed into a clean and dry crucible inside the glovebox. The crucible was inserted into the reactor and the reactor was assembled the same as it was for the $\mathrm{CCl}_{4}$ sparge step. The assembled reactor was taken out of the glovebox with rubber septa added to the three ports. The UHP Ar purging was done as described above. After 15 minutes of UHP Ar purging, the reactor was placed into the furnace heat zone and the assembly was done according to the same procedure described in the $\mathrm{CCl}_{4}$ sparge purification step. The heating profile for the UHP Ar/ $\mathrm{H}_{2}$ sparge is shown in Table 3 below.

Table 3. Heating and Cooling Profile of the UHP Ar/ $\mathrm{H}_{2}$ Sparge Purification

\begin{tabular}{|c|c|c|c|c|}
\hline $\begin{array}{c}\text { Temperature } \\
\left({ }^{\circ} \mathbf{C}\right)\end{array}$ & $\begin{array}{c}\text { Ramp rate } \\
\left({ }^{\circ} \mathbf{C} / \text { min) }\right.\end{array}$ & Dwell time (hr) & $\begin{array}{c}\text { Gas Flow Rate } \\
(\mathbf{L} / \mathbf{m i n})\end{array}$ & \begin{tabular}{c} 
Comments \\
\hline $25-750$
\end{tabular} \\
10 & & $>0.5$ & $\begin{array}{c}\text { @750 }{ }^{\circ} \mathrm{C} \text { dip the } \\
\text { sparge tube in the } \\
\text { melt }\end{array}$ \\
\hline 750 & N/A & $40 \mathrm{~h}$ & $>0.5$ & Start Ar/H sparge \\
\hline 750 & N/A & $0.5 \mathrm{~h}$ & $>0.5$ & $\begin{array}{c}\text { Sparge with UHP } \\
\text { Ar }\end{array}$ \\
\hline 750 & N/A & & $>0.5$ & $\begin{array}{c}\text { Remove the sparge } \\
\text { tube from the melt }\end{array}$ \\
\hline $750-25$ & Natural cooling & & $>0.5$ & \\
\hline
\end{tabular}

Purified Salt Handling. The final and intermediate purified salt batches were always handled under inert atmosphere inside the glovebox. Due to its extremely hygroscopic nature, the purified salt was never exposed to air during transferring, storing and various handling steps. 


\section{APPENDIX C: TITRATION PROCEDURE FOR OXIDE DETERMINATION}

Materials: A $500 \mathrm{~mL}$ three neck round bottom flask, stir bar, three rubber septa, $250 \mathrm{~mL}$ 's of $18.2 \mathrm{M} \Omega$ water, $\mathrm{pH}$ probe and accompanying meter, stir plate, standard buffer solutions, $0.01 \mathrm{M} \mathrm{NaOH}$ or $\mathrm{HCl}$ titrant (standardized against potassium hydrogen phthalate), and two needles

\section{Cleaning Procedure:}

1. New Round Bottom Flask and Stir Bar: If the glassware and stir bar have not been previously used for a titration then,

i. Begin by thoroughly washing the round bottom flask and stir bar with soap and deionized water

ii. Fill round bottom with $\geq 1.00 \mathrm{M} \mathrm{NaOH}$ or $\mathrm{KOH}$ made in $18.2 \mathrm{M} \Omega$ water, drop the stir bar into the flask and then allow flask with stir bar to sit overnight with basic solution

iii. The next day, rinse the round bottom and stir bar three times with $18.2 \mathrm{M} \Omega$ water then fill round bottom with $\geq 1.00 \mathrm{M} \mathrm{HCl}$ made in $18.2 \mathrm{M} \Omega$ water, drop the stir bar into the flask and then allow flask with stir bar to sit overnight with acidic solution

iv. The next day, dispose of the $\mathrm{HCl}$ solution and rinse the flask and stir bar six times with $18.2 \mathrm{M} \Omega$ water, blow pressurized air through the round bottom flask to remove the bulk of the water droplets on the flask and place in glass oven at $\geq 100^{\circ} \mathrm{C}$

v. Use a Kimwipe to dry the stir bar then place in a sealed container

2. Used Round Bottom Flask and Stir Bar: If the glassware and stir bar has only been used for titrations following step one cleaning procedure then,

i. Dispose of salt solution after titration (can be poured down the drain in the sink as long as the $\mathrm{pH}$ of the solution is between $\mathrm{pH} 5.00$ and 9.00 and solution does not contain a toxic salt mixture)

ii. Rinse the round bottom flask and stir bar with deionized water twice then three times with $18.2 \mathrm{M} \Omega$ water

iii. Use pressurized air to blow through the round bottom to remove the bulk of the water droplets, then place in the glass oven at $\geq 100^{\circ} \mathrm{C}$

iv. Use a Kimwipe to dry the stir bar then place in a sealed container

\section{Standard Titration:}

1. Remove the round bottom from the glass oven and clamp directly above the stir plate and allow glass to cool.

2. While the round bottom is cooling, measure out $250 \mathrm{~mL}$ of $18.2 \mathrm{M} \Omega$ water using a $500 \mathrm{~mL}$ graduated cylinder. After approximately 15 minutes when the round bottom flask has cooled to room temperature, add the $250 \mathrm{~mL}$ of $18.2 \mathrm{M} \Omega$ water to the flask.

3. Place the three septa on each of the three corresponding openings in the round bottom flask. Obtain two needles that are 18 gauge or larger (smaller gauge) and pierce the middle septa as well as one of the side septa. The needle in the middle septa will be used as the exhaust so ensure that it is well above the solution level. The needle through the side septa will be used to bubble argon gas through the $18.2 \mathrm{M} \Omega$ water so ensure the end of the needle is submerged at least two inches in the water. 
4. Connect the argon line to the submerged needle. Slowly turn on the gas flow so that there is a constant, steady stream of bubbles percolating through the solution. If the bubbles are agitating the solution to the point that water droplets are splashing on the walls of the flask above the solution level, then the flow rate is too fast.

5. Drop in the stir bar and turn on the stir plate to approximately $250 \mathrm{rpm}$. Allow solution to bubble/stir for 30 minutes to allow for removal of dissolved gasses in the water.

6. Calibrate the electrode using three standardized buffers and record the slope of the calibration. The acceptable range of the calibration is 97-103; if the slope is not within this range then try the calibration again with new standardized buffer solutions.

7. Weigh out the salt

8. After the water in the flask has purged for 30 minutes, replace the septa that is not pierced by a needle with the $\mathrm{pH}$ probe. Ensure that both the working electrode and reference (the two bulbs on the bottom of the probe) are totally submerged in the solution.

9. Pull the inlet gas needle from the solution, ensuring to keep the needle through the septa and above the solution with the gas still flowing to maintain an argon blanket inside the flask. Add salt to the solution. Use a clean disposable pipette to rinse any salt that adheres to the side of the flask and doesn't make it into the solution down the walls.

10. Allow the solution to stir for approximately 15 minutes to allow salt to dissolve and the $\mathrm{pH}$ to reach equilibrium.

11. Once the $\mathrm{pH}$ has reached equilibrium, record the $\mathrm{pH}$ and millivolt readout on the $\mathrm{pH}$ meter.

i. If the $\mathrm{pH}$ of the solution with the salt added is below 7.00, then the titrant that will be added will be $0.01 \mathrm{M} \mathrm{NaOH}$.

ii. If the $\mathrm{pH}$ of the solution with the salt added is above 7.00 , then the titrant to be added will be $0.01 \mathrm{M} \mathrm{HCl}$.

12. Add the corresponding titrant to the solution after it reaches equilibrium with the intention of moving the $\mathrm{pH}$ by between 0.10 to $0.50 \mathrm{pH}$ units after each addition of acid/base.

i. If there is a substantial amount of visible solid floating in the solution $\& \mathrm{pH}$ reading is $\geq 9.25$, then see section labeled spike titration.

ii. Add the titrant wait for the $\mathrm{pH}$ to reach equilibrium then record the volume and concentration of titrant added, the $\mathrm{pH}$ and millivolt readout of the solution once it has reached equilibrium.

iii. Continue this until one $\mathrm{pH}$ unit past neutral. 


\section{APPENDIX D: REFERENCES}

(1) Mehos, M.; Turchi, C.; Vidal, J.; Wagner, M.; Ma, Z.; Ho, C.; Kolb, W.; Andraka, C.; Kruizenga, A. Concentrating Solar Power Gen3 Demonstration Roadmap: Golden, CO2017.

(2) Ding, W.; Bonk, A.; Gussone, J.; Bauer, T. Cyclic Voltammetry for Monitoring Corrosive Impurities in Molten Chlorides for Thermal Energy Storage. Energy Procedia 2017, 135, 82-91.

(3) Ding, W. J.; Bonk, A.; Bauer, T. Corrosion behavior of metallic alloys in molten chloride salts for thermal energy storage in concentrated solar power plants: A review. Front. Chem. Sci. Eng. 2018, 12, 564-576.

(4) Ding, W. J.; Shi, H.; Xiu, Y. L.; Bonk, A.; Weisenburger, A.; Jianu, A.; Bauer, T. Hot corrosion behavior of commercial alloys in thermal energy storage material of molten $\mathrm{MgCl} 2 / \mathrm{KCl} / \mathrm{NaCl}$ under inert atmosphere. Sol. Energy Mater. Sol. Cells 2018, 184, 22-30.

(5) Gomez-Vidal, J. C.; Fernandez, A. G.; Tirawat, R.; Turchi, C.; Huddleston, W. Corrosion resistance of alumina forming alloys against molten chlorides for energy production. II: Electrochemical impedance spectroscopy under thermal cycling conditions. Sol. Energy Mater. Sol. Cells 2017, 166, 234-245.

(6) Li, Y.; Xu, X.; Wang, X.; Li, P.; Hao, Q.; Xiao, B. Survey and evaluation of equations for thermophysical properties of binary/ternary eutectic salts from $\mathrm{NaCl}, \mathrm{KCl}, \mathrm{MgCl} 2, \mathrm{CaCl} 2, \mathrm{ZnCl} 2$ for heat transfer and thermal storage fluids in CSP. Solar Energy 2017, 152, 57-79.

(7) Myers, P. D.; Goswami, D. Y. Thermal energy storage using chloride salts and their eutectics. Applied Thermal Engineering 2016, 109, 889-900.

(8) Vignarooban, K.; Xu, X. H.; Arvay, A.; Hsu, K.; Kannan, A. M. Heat transfer fluids for concentrating solar power systems - A review. Appl. Energy 2015, 146, 383-396.

(9) Xu, X. K.; Wang, X. X.; Li, P. W.; Li, Y. Y.; Hao, Q.; Xiao, B.; Elsentriecy, H.; Gervasio, D. Experimental Test of Properties of KCl-MgCl2 Eutectic Molten Salt for Heat Transfer and Thermal Storage Fluid in Concentrated Solar Power Systems. J. Sol. Energy Eng. Trans.-ASME 2018, 140.

(10) Le Brun, C. Molten salts and nuclear energy production. J. Nucl. Mater. 2007, 360, 1-5.

(11) LeBlanc, D. Molten salt reactors: A new beginning for an old idea. Nucl. Eng. Des. 2010, 240, 1644-1656.

(12) Williams, D. F.; Britt, P. F. Technology and Applied R\&D Needs for Molten Salt Chemistry: Innovative Approaches to Accelerate Molten Salt Reactor Development and Deployment: Oak Ridge, TN2017.

(13) Skar, R. A. Chemical and Electrochemical Characterization of Oxide/Hydroxide Impurities in the Electrolyte for Magnesium Production. Nnorges Teknisk-Naturvitenskapelige Universitet, 2001.

(14) Zhu, M.; Ma, H. F.; Wang, M. J.; Wang, Z. H.; Sharif, A. Effects of Cations on Corrosion of Inconel 625 in Molten Chloride Salts. High Temp. Mater. Process. 2016, 35, 337-345.

(15) Kruizenga, A. M. Corrosion Mechanisms in Chloride and Carbonate SAlts: Livermore, CA, September 20122012.

(16) Handbook of Preparative Inorganic Chemistry; Academic Press Inc.: New York, 1963.

(17) Chen, G. S.; Sun, I. W.; Sienerth, K. D.; Edwards, A. G.; Mamantov, G. Removal of Oxide Impurities from Alkali Haloaluminate Melts Using Carbon-Tetrachloride. J. Electrochem. Soc. 1993, 140, 1523-1526.

(18) Sun, I. W.; Sienerth, K. D.; Mamantov, G. The Use of Phosgene for the Removal of Oxide Impurities from a Sodium Chloroaluminate Melt Saturated with Sodium-Chloride. J. Electrochem. Soc. 1991, 138, 2850-2852.

(19) Young, J. P.; Mamantov, G.; Coffield, J. E.; Dai, S. In-line Sensors for Electrolytic Magnesium Cells: Oak Ridge, TN, ORNL/M/3003, 1993.

(20) Cho, H. S.; Van Zee, J. W.; Shimpalee, S.; Tavakoli, B. A.; Weidner, J. W.; Garcia-Diaz, B. L.; Martinez-Rodriguez, M. J.; Olson, L.; Gray, J. Dimensionless Analysis for Predicting Fe-Ni-Cr 
Alloy Corrosion in Molten Salt Systems for Concentrated Solar Power Systems. Corrosion 2016, 72, 742-760.

(21) Dai, S.; Young, J. P.; Mamantov, G. A New Sample Cell for Diffuse Reflectance IR Spectroscopy of Air-Sensitive Solid Samples. Appl. Spectrosc. 1991, 45, 1056-1058.

(22) Kipouros, G. J.; Sadoway, D. R. A thermochemical analysis of the production of anhydrous $\mathrm{MgCl}_{2}$. Journal of Light Metals 2001, 1, 111-117. 